\title{
Brenner tumor of the testis: A case report and review of the literature
}

\author{
JING QUAN ${ }^{1,2^{*}}$, LU JIN $^{1,2^{*}}$, JIA HU $^{2,3}$, TAO HE $^{2,3}$, XIANG PAN $^{1,2}$, YU DING $^{2}$, JIAN PENG $^{2}$, \\ ZHEBO CHEN $^{2}$, SHANGQI YANG ${ }^{2}$, XIANGMING MAO $^{2}$ and YONGQING LAI ${ }^{2}$ \\ ${ }^{1}$ Department of Urology, The First Clinical College, Anhui Medical University, Hefei, Anhui 230032; \\ ${ }^{2}$ Department of Urology, Peking University Shenzhen Hospital, Shenzhen, Guangdong 518036; ${ }^{3}$ Department of Urology, \\ Guangzhou Medical University, Guangzhou, Guangdong 510006, P.R. China
}

Received April 22, 2016; Accepted May 30, 2016

DOI: $10.3892 /$ mco.2016.1083

\begin{abstract}
Brenner tumor is a rare type tumor, which mainly develops in the ovaries and rarely in the adnexal region and urinary system. To the best of our knowledge, only 5 cases of testicular Brenner tumor have been reported to date. In this report, we present the case of a 55-year-old patient who noted a swelling of the right scrotum for $\sim 20$ days. The clinical suspicion was an epididymal cyst. However, following surgical resection and subsequent pathological examination, the mass was diagnosed as a testicular Brenner tumor. A supplementary review of previously published cases and literature is also presented. The aim of this report is to help elucidate this disease and reduce the rate of clinical and pathological misdiagnosis.
\end{abstract}

\section{Introduction}

Brenner tumor, an uncommon subtype of surface epithelialstromal tumors, which are a class of ovarian neoplasms, was first described by Brenner in 1907 (1). It is an uncommon neoplasm, accounting for $\sim 1.4-2.5 \%$ of all ovarian tumors (2). Brenner tumors are classified into three categories according to the World Health Organization, namely benign, borderline and malignant (3). Extraovarian Brenner tumors are extremely rare, and are mainly found in the broad ligament, uterus, vagina, testis and epididymis (4-7). In the present study, we report a case of Brenner tumor of the right testis and discuss the clinical and pathological characteristics of this disease. The study was approved by the Ethics Committee of Peking University Shenzhen Hospital (Shenzhen, China) and

Correspondence to: Professor Yongqing Lai, Department of Urology, Peking University Shenzhen Hospital, 1120 Lianhua Road, Shenzhen, Guangdong 518036, P.R. China

E-mail: yqlord@163.com

${ }^{*}$ Contributed equally

Key words: Brenner tumor, testis, cystic mass written informed consent was obtained from the patient for the publication of the case details.

\section{Case report}

The patient, a A 55-year-old man presented with a swelling of the right scrotum for $\sim 20$ days. There were no obvious precipitating or alleviating factors. The patient experienced a painless sensation of heaviness of the right testis. The only positive physical finding was a mildly tender mass in the right scrotum. The results of the laboratory and imaging examinations (hemogram, urinalysis, $\beta$-human chorionic gonadotropin, a-fetoprotein, liver and kidney function tests and chest X-ray) were normal. However, the results of a superficial color Doppler ultrasound examination suggested that the right scrotum had multiple cystic lesions, and an epididymal was considered as the possible clinical diagnosis.

Following the doctors' recommendation, the patient consented to right epididymal cystectomy in Novermber, 2013. During the operation, the cyst was found to be located between the testis and the head of the epididymis and was sized $\sim 50 \times 30 \mathrm{~mm}$. The cyst exhibited inflammatory adhesions to the surrounding organs, although invasion was not observed. On gross pathological examination, the resected specimen was a cyst with a thin wall $(1 \mathrm{~mm})$, sized $6.5 \times 4 \times 3.5 \mathrm{~cm}$, containing a clear liquid. On microscopic examination, the fibrous cystic wall was coated with a monolayer or stratified squamous epithelium. Epithelium-like nests and a small quantity of epididymal canal tissue were also identified (Fig. 1). The pathological diagnosis was Brenner tumor of the right testis. Postoperatively, the patient recovered well. After 29 months of follow-up, the patient has no evidence of recurrence on laboratory and imaging examinations.

\section{Discussion}

Brenner tumor is a rare ovarian tumor, which was first identified by McNaughton-Jones in 1989, and was then first described in detail by Brenner in 1907 (1). Brenner tumors are similar to Walthard nests and tubal/mesothelial transitional metaplasia, which are composed of urothelial/transitional-type epithelium. It remains a matter of debate whether ovarian-type epithelial 
Table I. Brenner tumor of the testis.

\begin{tabular}{|c|c|c|c|c|c|c|}
\hline $\begin{array}{l}\text { Authors, } \\
\text { year }\end{array}$ & $\begin{array}{c}\text { Patient } \\
\text { age (years) }\end{array}$ & Presentation & Location & Size $(\mathrm{cm})$ & Histology & (Refs.) \\
\hline Caccamo et al, 1991 & 62 & Unknown & $\begin{array}{l}\text { Testis and } \\
\text { epididymis }\end{array}$ & Unknown & Brenner tumor & (7) \\
\hline Ronald and Goldman, 1970 & 41 & $\begin{array}{l}\text { Vague intermittent } \\
\text { aching sensation } \\
\text { and tender mass }\end{array}$ & Left testis & $2.7 \times 2.2 \times 2.0$ & Brenner tumor & (8) \\
\hline Nogales et al, 1979 & 37 & Cystic mass & Testis & 3 & $\begin{array}{l}\text { Mixed Brenner and } \\
\text { adenomatoid tumor }\end{array}$ & (14) \\
\hline Ross et al, 1968 & 61 & $\begin{array}{l}\text { Diabetes with } \\
\text { cardiovascular } \\
\text { complications }\end{array}$ & Paratesticular & $\begin{array}{l}6 \mathrm{~mm} \text { in } \\
\text { greatest } \\
\text { diameter }\end{array}$ & Brenner tumor & (15) \\
\hline Vechinski et al, 1965 & 67 & $\begin{array}{l}40 \text {-year history } \\
\text { of inguinal hernia } \\
\text { and swelling of the } \\
\text { scrotum in } 4 \text { weeks }\end{array}$ & Testis & 7.3 & Brenner tumor & (16) \\
\hline
\end{tabular}

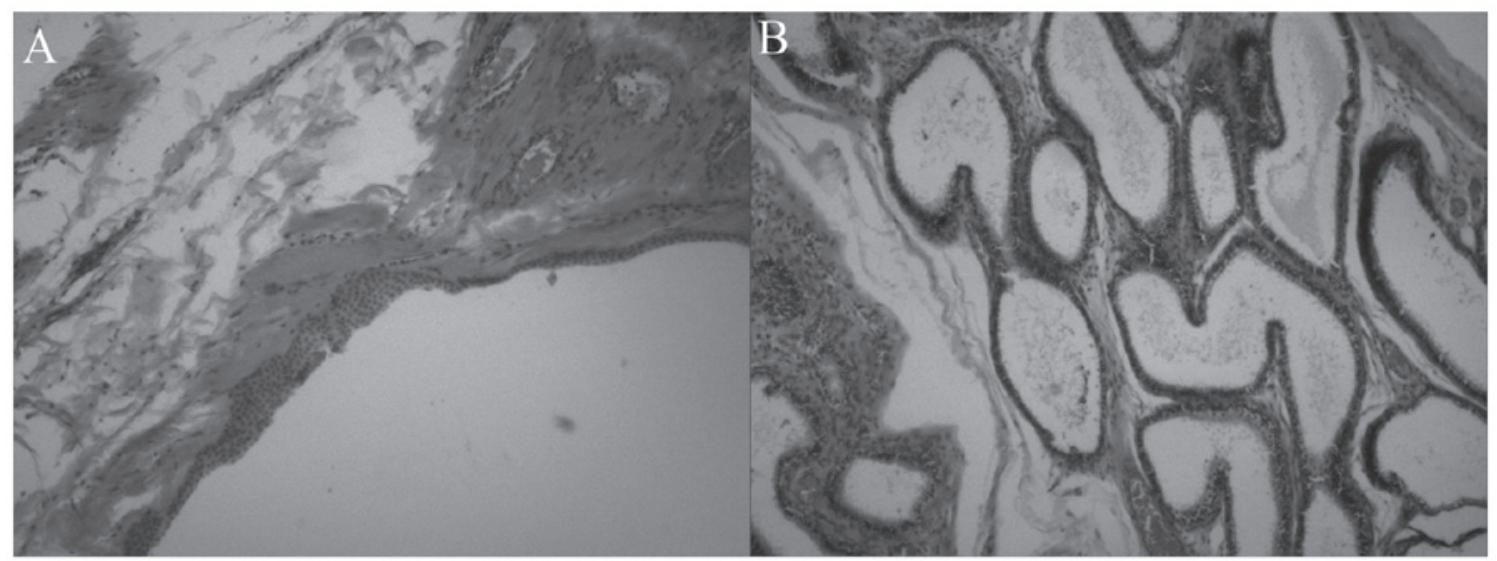

Figure 1. (A) View of the epithelium-like nests. The nests were surrounded by a dense stroma and the boundaries were clear. The size and shape of the cells in the epithelium-like nests was almost identical. (B) A small amount of epididymal canal tissue was present.

tumors of the testis originate from the remnants of Müllerian ducts in the paratesticular connective tissue, epididymis and spermatic cord, or from Müllerian metaplasia of the mesothelium of the tunica vaginalis testis. Goldman considered Brenner tumors in the testis to originate from Müllerian vestiges, as the testis and epididymis originated from these structures (8), whereas Arhelger and Bocian believed that Brenner tumors in the wall of the uterus were formed by Walthard nests (9). With clearer understanding of Brenner tumors, scholars have realized that the urinary epithelial cells and ovarian epithelial cells originate from coelomic epithelial cells during embryonic development. Thus, it is possible that the urinary epithelium develops from ovarian epithelium through metaplasia (10).

It is difficult to diagnose Brenner tumors by imaging examinations, due to the lack of specific morphological characteristics $(11,12)$. A number of pathologists suggest that Brenner tumors are similar to Walthard nests in morphology, suggesting an association between the two. Thus, Roma and
MasandAnders analyzed immunohistochemical markers in Brenner tumors and Walthard nests, such as paired box (PAX) 8, PAX2, spalt-like transcription factor 4 and GATA-binding protein 3. The results suggested that Brenner tumors may be immunohistochemically related to Walthard nests (13).

ly rare. To the best of our knowledge, only 5 cases of Brenner tumor of the testis have been described to date $(7,8,14-16)$ with our patient being the sixth reported case. The previous cases are summarized in Table I (full details on the fifth report were not available). Upon reviewing the diagnosis and treatment of the 6 cases, the following shared characteristics were identified: i) The age at onset was $37-67$ years, with $66.7 \%$ of the patients aged $>50$ years; ii) a cystic mass was the most common clinical manifestation, but the characteristics and size of the mass varied; iii) diagnosis is based on pathological examination. As this type of tumor is not associated with typical clinical symptoms, without specific laboratory results and 
imaging examinations, it is often misdiagnosed as hydrocele or epididymal cancer; iv) due to the sparsity of reported cases, the survival rate is uncertain; however, based on the available studies on Brenner tumor of the ovary, survival depends on the stage of the tumor. In general, following surgery, the prognosis of benign Brenner tumor is good, while the prognosis of malignant Brenner tumor is poor. The 5-year survival of stage III/IV disease is $\sim 0 \%$, with only 1 known case surviving for $>2$ years following intensive systemic chemotherapy (1).

In conclusion, Brenner tumor is rare and difficult to diagnose, particularly when occurring in unusual locations. This report presents a case of Brenner tumor of the testis, which is the sixth known case of testicular Brenner tumor. This report may be helpful in further elucidating this disease and reducing the rate of clinical and pathological misdiagnosis.

\section{Acknowledgements}

The present study was supported by grants from the National Natural Science Foundation of China(no.81101922), the Science and Technology Development Fund Project of Shenzhen (nos. JCY20130402114702124 and JCY20150403091443329) and funds from the Guangdong Key Medical Subject.

\section{References}

1. Han JH, Kim DY, Lee SW, Park JY, Kim JH, Kim YM, Kim YT and Nam JH: Intensive systemic chemotherapy is effective against recurrent malignant Brenner tumor of the ovary: An analysis of 10 cases within a single center. Taiwan J Obstet Gynecol 54: 178-182, 2015. [J].

2. Verma A, Chander B, Verma S and Soni A: Malignant brenner tumor of ovary. J Obstet Gynaecol India 64: 148-149, 2014.
3. Böcker W: WHO classification of breast tumors and tumors of the female genital organs: Pathology and genetics. Verh Dtsch Ges Pathol 86: 116-119, 2002.

4. Leoncini L: Brenner tumor of the broad ligament. Arch De Vecchi Anat Patol 64: 97-102, 1980.

5. Angeles-Angeles A, Gutiérrez-Villalobos LI, Lome-Maldonado C and Jiménez-Moreno A: Polypoid Brenner tumor of the uterus. Int J Gynecol Pathol 21: 86-87, 2002.

6. Shaco-Levy R and Benharroch D: Vaginal brenner tumor. Int J Gynecol Pathol 32: 238-241, 2013.

7. Caccamo D, Socias M and Truchet C: Malignant Brenner tumor of the testis and epididymis. Arch Pathol Lab Med 115: 524-527, 1991.

8. Goldman RL: A brenner tumor of the testis. Cancer 26: 853-856, 1970.

9. Arhelger RB and Bocian JJ: Brenner tumor of the uterus. Cancer 38: 1741-1743, 1976.

10. Bürger T, Schildhaus HU, Inniger R, Hansen J, Mayer P, Schweyer S, Radzun HJ, Ströbel P and Bremmer F: Ovarian-type epithelial tumours of the testis: Immunohistochemical and molecular analysis of two serous borderline tumours of the testis. Diagn Pathol 10: 118, 2015. [J].

11. Dierickx I, Valentin L, Van Holsbeke C, Jacomen G, Lissoni AA, Licameli A, Testa A, Bourne T and Timmerman D: Imaging in gynecological disease (7): Clinical and ultrasound features of Brenner tumors of the ovary. Ultrasound Obstet Gynecol 40: 706-713, 2012. [J].

12. Moon WJ, Koh BH, Kim SK, Kim YS, Rhim HC, Cho OK, Hahm CK, Byun JY, Cho KS and Kim SH: Brenner tumor of the ovary: CT and MR findings. J Comput Assist Tomogr 24: 72-76, 2000.

13. Roma AA and Masand RP: Ovarian Brenner tumors and Walthard nests: A histologic and immunohistochemical study. Hum Pathol 45: 2417-2422, 2014.

14. Nogales FF Jr, Matilla A, Ortega I and Alvarez T: Mixed Brenner and adenomatoid tumor of the testis: An ultrastructural study and histogenetic considerations. Cancer 43: 539-543, 1979.

15. Ross L: Paratesticular Brenner-like tumor. Cancer 21: 722-726, 1968.

16. Vechinski TO, Jaeschke WH and Vermund H: Testicular tumors. An analysis of 112 consecutive cases. Am J Roentgenol Radium Ther Nucl Med 95: 494-514, 1965. 